
INFLAMMATORY ARTHRITIS: A TEAM WORK

M. Brignon ${ }^{1}$, C. Vioulac ${ }^{2}$, E. Boujut ${ }^{2}$, C. Delannoy ${ }^{3}$, C. Beauvais ${ }^{4}$, J.-S. Giraudet Lequintrec $^{4}$, D. Poivret ${ }^{5}$, J. Kivits ${ }^{1}$, A. Untas ${ }^{2}$, A.-C. Rat. ${ }^{1}{ }^{1}$ EA4360, Université de Lorraine, Nancy, ${ }^{2}$ EA 4057, ${ }^{3}$ Paris Descartes University, ${ }^{4}$ APHP, Paris, ${ }^{5}$ Metz, Metz, France

Background: Adjustment to inflammatory arthritis (IA) is complex for the patient but also for the relative and there is room for improvement in the support provided to the dyad

Objectives: to explore patients and relatives experience of IA, their difficulties, mutual expectations, communication, coping strategies and needs

Methods: Participants were recruited by 7 rheumatologists during their consultations. Eligibility criteria were: having a rheumatoid arthritis (RA) or a spondyloarthritis $(\mathrm{SpA})$. Relatives were invited to participate by the patients. Face to face interviews with the dyad were conducted by 3 psychologists with an interview guide built by the project working group. A thematic analysis was conducted by 2 psychologists, following a general inductive approach

Results: 20 patients and their relative (18 partners, 1 mother, 1 friend) were included: $13 \mathrm{RA}$ and $7 \mathrm{SpA}$, median disease and couple duration 10 (range 1-36) and 28 years (range 1.5-57). The analysis revealed 4 main themes: disease leaved together, impact of the disease on the relationship, social impact of the disease on the dyad, difficulties and needs of the relative. Disease leaved together: dyads explained the new roles of the relative: providing material help, understanding and emotional support, acting as a driving force, take part of medical care (medical decisions, support in adhesion, searching for information). Communication around the disease is an important theme; reasons to avoid talking about the disease were: not focusing on the disease, respecting the need to be alone, words are not always needed. For other dyads, talking about the disease allows for improving knowledge about the disease or for security reasons. Impact of the disease on the relationship: if they do not feel the IA has changed their relationship, they acknowledged some tensions because of the disease: disease get too much attention in their relationship, lack of communication create tensions. Social impact of the disease on the dyad: social isolation was highlighted: patients need sometimes to be alone, invisibility of the disease creates misunderstandings, people around don't realize what it means to live with IA. Unpredictability of the symptoms makes it difficult to organize everyday life and to have projects. Difficulties and needs of the caregiver were rarely raised when the dyads were interviewed together: sometimes disease is not well accepted by the caregiver, not being able to help is frustrating, finding the right way to help is difficult. Knowledge of the disease and the patient symptoms are important needs expressed by the caregiver Conclusions: The current qualitative study offers new insights into the perception of patient and relative of their shared life with the disease and is a first step to develop interventions to support them. This study has highlighted the importance of the recognition of the role of the relative in the disease management. Joint approach to treatment is a basis for coping with the disease. This supposes: 1) a good understanding of one another, which can be improved by providing information on the disease, its symptoms and coping strategies to both the patient and the relative 2) shared determination of relative roles 3 ) good communication skills Disclosure of Interest: None declared

DOI: 10.1136/annrheumdis-2018-eular.5503

\section{FRI0701 FRENCH SPECIALISTS AND IMMUNE-RELATED ADVERSE EVENTS OF CANCER IMMUNOTHERAPY: A STATE OF THE ART FROM SEVERAL NATIONAL EXPERT NETWORKS.}

M. Kostine ${ }^{1}$, C. Richez ${ }^{1}$, J.-E. Gottenberg ${ }^{2}$, O. Lambotte ${ }^{3} .{ }^{1}$ Bordeaux University Hospital, Bordeaux, ${ }^{2}$ Strasbourg University Hospital, Strasbourg, ${ }^{3}$ Le KremlinBicêtre, Paris, France

Background: Immunotherapeutic strategies with immune checkpoint inhibitors (ICl) are now commonly used in treating patients with advanced-stage cancer. An important proportion of patients experiences inflammatory or autoimmune side effects, also known as immune-related adverse events (irAEs), as a consequence of dysregulated immunity which can affect any organ system (1). A recent survey conducted by our colleagues from United States highlighted that rheumatologists had limited experience and lacked confidence in the management of rheumatic irAEs (2).

Objectives: To evaluate the knowledge of French specialists regarding $\mathrm{ICl}$ and irAEs through an online survey.

Methods: The online survey has been sent in January 2018 to several French national expert networks: Société Française de Rhumatologie (SFR), Club Rhumatismes et Inflammations (CRI), Société Nationale de Médecine Interne (SNFMI), Groupe d'Etude Thérapeutique des Affections Inflammatoires du Tube Digestif (GETAID) and Société Française d'Endocrinologie (SFE).

Results: 349 French specialists participated to this study: rheumatologists $(n=159)$, internists $(n=112)$, endocrinologists $(n=55)$, gastroenterologists $(n=22)$ and one respiratory physician. As detailed in table $\mathbf{1}$, participants were mainly working in academic or hospital with various levels of experience in clinical practice. Overall, half of the specialists reported some basic knowledge of $\mathrm{ICl}$ and irAEs. Around $25 \%$ either have never heard about these therapies and their side effects or were not knowledgeable. The majority of the participants has never or rarely managed irAEs ( $31 \%$ and $40 \%$ respectively), and only $11 \%$ declared being very confident in treating such patients. The type of content requested for education was mainly about treatment algorithms $(80 \%)$ followed by clinical description of irAEs (59\%) then general information on $\mathrm{ICl}$ (mechanism of action, administration, efficacy).

\begin{tabular}{|c|c|c|c|c|c|c|}
\hline & $\begin{array}{l}\text { Rheumatologists } \\
(n=159)\end{array}$ & $\begin{array}{l}\text { Internists } \\
(n=112)\end{array}$ & $\begin{array}{l}\text { Endocrinologists } \\
(n=55)\end{array}$ & $\begin{array}{l}\text { Gastroent } \\
(n=22)\end{array}$ & $\begin{array}{l}\text { ts Pulmon } \\
(n=1)\end{array}$ & $\begin{array}{c}t \text { Total } \\
(=349)\end{array}$ \\
\hline \multicolumn{7}{|c|}{ 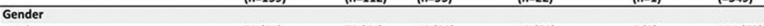 } \\
\hline Male & & & & & & \\
\hline Female & $78(49)$ & $40(36)$ & $37(67)$ & $9(41)$ & $1(100)$ & $165(47)$ \\
\hline \multicolumn{7}{|l|}{ Practice setting } \\
\hline Academic hospital & $54(34)$ & $57(51)$ & $21(38)$ & $15(68)$ & $0(0)$ & $147(42)$ \\
\hline Non-academic hospital & $29(18)$ & $38(34)$ & $14(26)$ & $5(23)$ & $0(0)$ & $86(25)$ \\
\hline & & & & & & \\
\hline Mixed (private \& hospital) & $32(20)$ & $5(4)$ & $10(18)$ & $1(4.5)$ & $1(100)$ & $49(14)$ \\
\hline Residents / in training & $3(2)$ & $3(3)$ & $1(2)$ & $0(0)$ & $0(0)$ & $7(2)$ \\
\hline \multicolumn{7}{|l|}{ Years of medical practice } \\
\hline$<10$ & $41(26)$ & $39(35)$ & $13(24)$ & $8(36)$ & $0(0)$ & $101(29)$ \\
\hline $10-20$ & $45(28)$ & $37(33)$ & $14(26)$ & $10(45.5)$ & $1(100)$ & $107(31)$ \\
\hline $20 \cdot 30$ & $38(24)$ & $21(19)$ & $15(26)$ & $3(14)$ & $0(0)$ & $77(22)$ \\
\hline \multirow{2}{*}{\multicolumn{7}{|c|}{ Knowledge of ICI }} \\
\hline & & & & & & \\
\hline $\begin{array}{l}\text { None } \\
\text { I have heard of ICI }\end{array}$ & $\begin{array}{l}59(3) \\
49(31)\end{array}$ & $\begin{array}{l}35(22) \\
251\end{array}$ & $\begin{array}{l}1(2) \\
9(16)\end{array}$ & $\begin{array}{l}299 \\
2(9)\end{array}$ & $\begin{array}{l}0(0) \\
0(0)\end{array}$ & $\begin{array}{l}11(3) \\
85(24)\end{array}$ \\
\hline Some basic knowledge & $71(44)$ & $61(55)$ & $28(51)$ & $11(50)$ & $1(100)$ & $172(49)$ \\
\hline Familiar & $27(17)$ & $15(13)$ & $12(22)$ & $7(32)$ & $0(0)$ & $61(18)$ \\
\hline $\begin{array}{l}\text { Very familiar } \\
\text { Knaldrafs }\end{array}$ & $7(5)$ & $8(7)$ & $5(9)$ & $0(0)$ & $0(0)$ & $20(6)$ \\
\hline \multicolumn{7}{|l|}{ Knowledge of irAes } \\
\hline $\begin{array}{l}\text { None } \\
\text { thave heard of itAEs }\end{array}$ & $\begin{array}{l}14(9) \\
30(19)\end{array}$ & $\begin{array}{l}8(7) \\
21(19)\end{array}$ & $\begin{array}{l}3(5) \\
6(11)\end{array}$ & $2(9)$ & $0(0)$ & $\begin{array}{l}278) \\
58(177)\end{array}$ \\
\hline $\begin{array}{l}\text { Thave heard of IfAes } \\
\text { Some basic knowledge }\end{array}$ & $\begin{array}{l}70(19) \\
72(45)\end{array}$ & $\begin{array}{l}211(19) \\
56(50)\end{array}$ & $23(42)$ & $\begin{array}{l}1(4.4) \\
9(41)\end{array}$ & $\begin{array}{l}0(10) \\
1(100)\end{array}$ & 581170 \\
\hline $\begin{array}{l}\text { Somiliar } \\
\text { Fatic knowie eage }\end{array}$ & $\begin{array}{l}31(19) \\
31\end{array}$ & $17(15)$ & $17(31)$ & $7(32)$ & $0(0)$ & $72(20)$ \\
\hline Very familiar & $12(8)$ & $\begin{array}{l}10(9) \\
109\end{array}$ & $6(11)$ & $3(13.5)$ & $0(0)$ & $31(9)$ \\
\hline \multicolumn{7}{|l|}{ Management of $p$} \\
\hline Never & $58(36)$ & $40(36)$ & $5(9)$ & $6(27)$ & $0(0)$ & $109(31)$ \\
\hline Maybe, but Ididn't link symptoms with ICI & $15(10)$ & & & $0(0)$ & & $26(8)$ \\
\hline Rarely & $64(40)$ & $44(40)$ & $22(40)$ & $9(41)$ & $1(100)$ & $140(40)$ \\
\hline Several times (>5 patients) & $17(11)$ & $16(14)$ & $12(22)$ & $5(23)$ & $0(0)$ & $50(14)$ \\
\hline Frequently (>10 patients) & $5(3)$ & $5(4)$ & $12(22)$ & $2(9)$ & $0(0)$ & $24(7)$ \\
\hline \multicolumn{7}{|l|}{ Level of confidence } \\
\hline I don't know the topic & $21(13)$ & $6(6)$ & $5(9)$ & $2(9)$ & $0(0)$ & $34(10)$ \\
\hline Not confident & $\begin{array}{l}28(18) \\
33(20)\end{array}$ & $29(26)$ & $7(12)$ & $3(14)$ & $1(100)$ & $68(19)$ \\
\hline $\begin{array}{l}\text { Somewhat confident } \\
\text { Moderately }\end{array}$ & $\begin{array}{l}32(20) \\
65(4) 1 \\
6\end{array}$ & $\begin{array}{l}35(31) \\
34(30)\end{array}$ & $\begin{array}{l}13(24) \\
17(31)\end{array}$ & $3(14)$ & $0(0)$ & $83(24)\}$ \\
\hline $\begin{array}{l}\text { Moderately confident } \\
\text { Very confident. }\end{array}$ & $\begin{array}{l}65(14) \\
13(8)\end{array}$ & $\begin{array}{l}3(7)(30) \\
8(2)\end{array}$ & $13(24)$ & $4(18)$ & $0(0)$ & $38(11)$ \\
\hline
\end{tabular}

Conclusions: Since there has been an increasing emphasis on irAEs within the last three years, we confirmed the need of a dedicated medical education regarding this new clinical entity.

\section{REFERENCES :}

(1) Postow MA, Sidlow R, Hellmann MD. Immune-Related Adverse Events Associated with Immune Checkpoint Blockade. N Engl J Med. 2018 Jan $11 ; 378(2): 158-168$

(2) Cappelli L, Calabrese C, Calabrese LH, Bingham III CO. ImmunotherapyInduced Rheumatic Disease: How Prepared Are Rheumatologists to Address This Emerging Condition? [Abstract]. Arthritis Rheumatol 2017;69 (suppl 10).

Acknowledgements: We thank all respondents for their active participation Disclosure of Interest: None declared

DOI: 10.1136/annrheumdis-2018-eular.7371 